\title{
How does the quality of surveys for nutrient intake adequacy assessment compare across Europe? A scoring system to rate the quality of data in such surveys
}

\author{
Alicia García-Álvarez ${ }^{1}$, Maria Blanquer ${ }^{1}$, Lourdes Ribas-Barba ${ }^{1}$, Trudy M. A. Wijnhoven ${ }^{2}$, \\ Garden Tabacchi ${ }^{3}$, Mirjana Gurinovic ${ }^{4}$ and Lluís Serra-Majem ${ }^{1,5 *}$ \\ ${ }^{1}$ Community Nutrition Research Centre of the Nutrition Research Foundation, University of Barcelona Science Park, Baldiri \\ Reixac 4, 08028 Barcelona, Spain \\ ${ }^{2}$ Noncommunicable Diseases and Environment, World Health Organization Regional Office for Europe, Scherfigsvej 8 , DK-2100 \\ Copenhagen $\emptyset$, Denmark \\ ${ }^{3}$ Institute of Physiology and Human Nutrition, University of Palermo, Via Augusto Elia 3, 90127 Palermo, Italy \\ ${ }^{4}$ Department for Nutrition and Metabolism, Institute for Medical Research, University of Belgrade, Tadeusa Koscuska 1, Belgrade \\ 11000, Serbia and Montenegro \\ ${ }^{5}$ Department of Clinical Sciences, University of Las Palmas de Gran Canaria, PO Box 550, 35080 Las Palmas de Gran Canaria, \\ Spain
}

(Received 4 February 2009 - Revised 6 May 2009 - Accepted 1 June 2009)

Research was conducted within the EURopean micronutrient RECommendations Aligned (EURRECA) Network of Excellence, to find the best practice in assessing nutrient intakes. Objectives include: to search for and use data on individual nutrient intake adequacy (NIA) assessment collected in twenty-eight European countries and the four European Free Trade Association countries; to design and test innovative tools for data quality analysis. The information was obtained using the method described by Blanquer et al. in the present issue. The best-practice criteria were devised to select the most appropriate survey in each country. Then a survey quality scoring system was developed in consultation with experts and tested on these surveys. Weights were allocated according to a variable priority order agreed by consultation. The thirty-two countries yielded twenty-four national surveys (eight countries excluded). Data collection techniques: eleven countries/surveys used personal interviews only; six used combinations of techniques. Dietary assessment methods: two used repeated $24 \mathrm{~h}$ recalls only; eleven used combinations. NIA assessment methods: two used probabilistic approach and SD/Z-scores only; eleven used comparison with estimated average requirements/RDA only. Countries were ranked according to the survey quality scoring, but careful interpretation is needed because of incomplete data from some surveys; bearing this in mind, the information quality is high in $37.5 \%$ countries, medium in $50.0 \%$ and low in $12.5 \%$. Although there is room for improvement and caution should be taken when drawing conclusions and recommendations from these results, the lessons learned and tools developed at this first attempt form the basis for future work within the EURRECA framework for aligning European micronutrient recommendations.

Nutrient intake adequacy: Assessment methods: Best practice: European survey quality

Several studies have recently compared or are presently in the process of comparing dietary intake at the European level (DAta Food NETworking (DAFNE) ${ }^{(1,2)}$, European Food Consumption Survey Method (EFCOSUM) ${ }^{(3)}$, European Food Consumption Validation (EFCOVAL) ${ }^{(4)}$. European Prospective Investigation into Cancer and Nutrition (EPIC) ${ }^{(5)}$, Europe Alimentation (EPIC) ${ }^{(6)}$, European Nutrition and Health
Report 2004 and 2009 ((EURALIM) ENHR I and II) ${ }^{(7,8)}$ ), each having different objectives and focusing on different aspects of the dietary information available. For instance, the EURALIM sought to improve ways of comparing European data on health-related risk factors from projects carried out in six European countries (in subjects aged 40-59 years as common age in all projects) ${ }^{(9)}$.

Abbreviations: EFCOSUM, European Food Consumption Survey Method; ENHR I and II, European Nutrition and Health Report 2004 and 2009; EURRECA, EURopean micronutrient RECommendations Aligned; NIA, Nutrient Intake Adequacy.

On behalf of EURRECA's research activity 1.1 'Intake Methods' members: Serra-Majem L (Coordinator), Cavelaars A, Dhonukshe-Rutten R, Doreste JL, Frost-Andersen L, García-Álvarez A, Glibetic M, De Groot L, Henríquez-Sánchez P, Naska A, Ngo J, Novakovic R, Ortiz-Andrellucchi A, Øverby NC, Gurinovic M, Pijls L, Ranic M, Ribas-Barba L, Ristic-Medic D, Román-Viñas B, Ruprich J, Saavedra-Santana P, Sánchez-Villegas A, Tabacchi G, Tepsic J, Trichopoulou A, van 't Veer P, Vucic V, Wijnhoven TMA.

* Corresponding author: Professor Lluís Serra-Majem, fax +3493403 4543, email lserra@dcc.ulpgc.es 
The EFCOSUM project aimed at finding a new method for collecting comparable food intake data in Europe, considering both pre- and post-harmonisation, i.e. collecting the raw data to later compare it or otherwise making existing data comparable $^{(3)}$. Nowadays, food availability data from household budget surveys (e.g. the DAFNE project) are already comparable across countries ${ }^{(1,2)}$. In addition, the methods developed by the EPIC study ${ }^{(5)}$ allowed the collection of comparable individual intake data, but its focus was only on cancer and adults. Therefore, it is necessary that European countries harmonise intake data at the individual level that can be compared within a wider context. In this direction, the European Food Safety Authority (EFSA) has developed the Concise European Food Consumption database $^{(10)}$ with the intention to provide a valuable first screening tool (to EFSA, its scientific panels and potentially to other scientists in Member States) to help carry out preliminary exposure assessments. EFSA seeks to use this concise database as the starting point of a more comprehensive database, with information on more refined food categories and specific population groups. In order to meet the aim of aligning micronutrient recommendations across Europe as part of the EURopean micronutrient RECommendations Aligned (EURRECA) Network of Excellence, some EURRECA partners have already produced one study, whose objective was to understand the differences and similarities of the present micronutrient recommendations in Europe $^{(11)}$ and another one to produce an evidence-based toolkit to support nutrition and food policy ${ }^{(12)}$. The objective of the present paper is to give an overall picture of the present European situation with regard to the methods used for evaluating nutrient intake. This is achieved by comparing the information available on nutrient intake adequacy (NIA) assessment and dietary collection methods in national nutrition/health surveys/studies on healthy adults of twentyeight European countries and the four European Free Trade Association countries (Iceland, Liechtenstein, Norway, Switzerland). This comparison will help identify the information gaps as a starting point for future European micronutrient recommendations on the best practice regarding intake methods. For this purpose, identified information as described by Blanquer et al. ${ }^{(13)}$ is analysed and the response to their questionnaire for data collection used as a databank for obtaining quantitative results. A best-practice guide and a survey/study quality scoring system have also been developed for qualitative analyses and proposed as tools to be used by future EURRECA research activities.

\section{Methodology}

The step-wise methodological process followed to obtain the information used in the present paper has been thoroughly described by Blanquer et al. ${ }^{(13)}$, who presented an overview of the methodological framework in Fig. 1. A brief summary of Blanquer's methodological framework is described herein.

\section{The 'Country information found' table and the pan-European questionnaire}

A literature search and review was carried out. The sources of information were PubMed MEDLINE, EURRECA partners and selected stakeholders, and websites of country-specific ministries of agriculture or health. All the results obtained were screened using the exclusion criteria ${ }^{(13)}$ on two consecutive occasions, until final results were obtained and entered into an Excel databank: the 'Country information found' table.

Parallel to the literature reviews, a questionnaire was designed and a country-specific list of experts compiled; the preliminary version of the questionnaire was circulated for its review among EURRECA's research activity 1.1 members, all EURRECA members and experts of the ENHR $I^{(7)}$. The final version of the questionnaire incorporated the feedback from all three groups and, together with a summary table containing country-specific information found, it was sent to an average of two to five food consumption experts per country. A total of three reminder follow-ups were sent to non-respondents.

The present paper is based on data extracted from the questionnaire completed by country experts, whose response has been analysed for obtaining quantitative results. The rest of the information found by Blanquer et al. ${ }^{(13)}$ was used to complete relevant information gaps of the questionnaires when necessary.

How to select 'the best' dietary survey/study per country: the best-practice guide for future activities within EURRECA

The concept of 'toolkit' developed within the EURRECA framework $^{(12)}$, and in the context of the present paper, denotes a step-by-step guidance diagram summarising the process followed to select the 'best' or the 'highest quality' dietary survey/study in each country considered; this toolkit was developed to facilitate the best practice for future EURRECA's research activities. A set of guidelines was formulated to increase comparability of the data obtained (Fig. 1), some of them in accordance with EFCOSUM's recommendations ${ }^{(3)}$ :

1. standardise data presentation through a same questionnaire sent to experts for completion;

2. only one survey/study per country can be considered; thus, in the present paper, the words 'survey/study' and 'country' will have the same meaning when it comes to results;

3. surveys/studies of cross-sectional nature;

4. the most representative survey/study of the country's population (to maximise external validity) - ideally at the national level (otherwise regional or, lastly, local levels);

5. the most recent surveys/studies (only include those conducted after 1990);

6. surveys/studies with the best methodology in accordance to their objectives (to maximise internal validity)

The type of survey/study was also an important element, ideally selecting those focused on nutrition firstly, health surveys with nutritional data secondly, or household budget surveys with nutritional data in third place. Combinations of regional or local levels with health or household budget surveys/studies were excluded (Fig. 1).

Finally, only surveys/studies on the adult population (defined as 18-65 years) were considered, since a first 


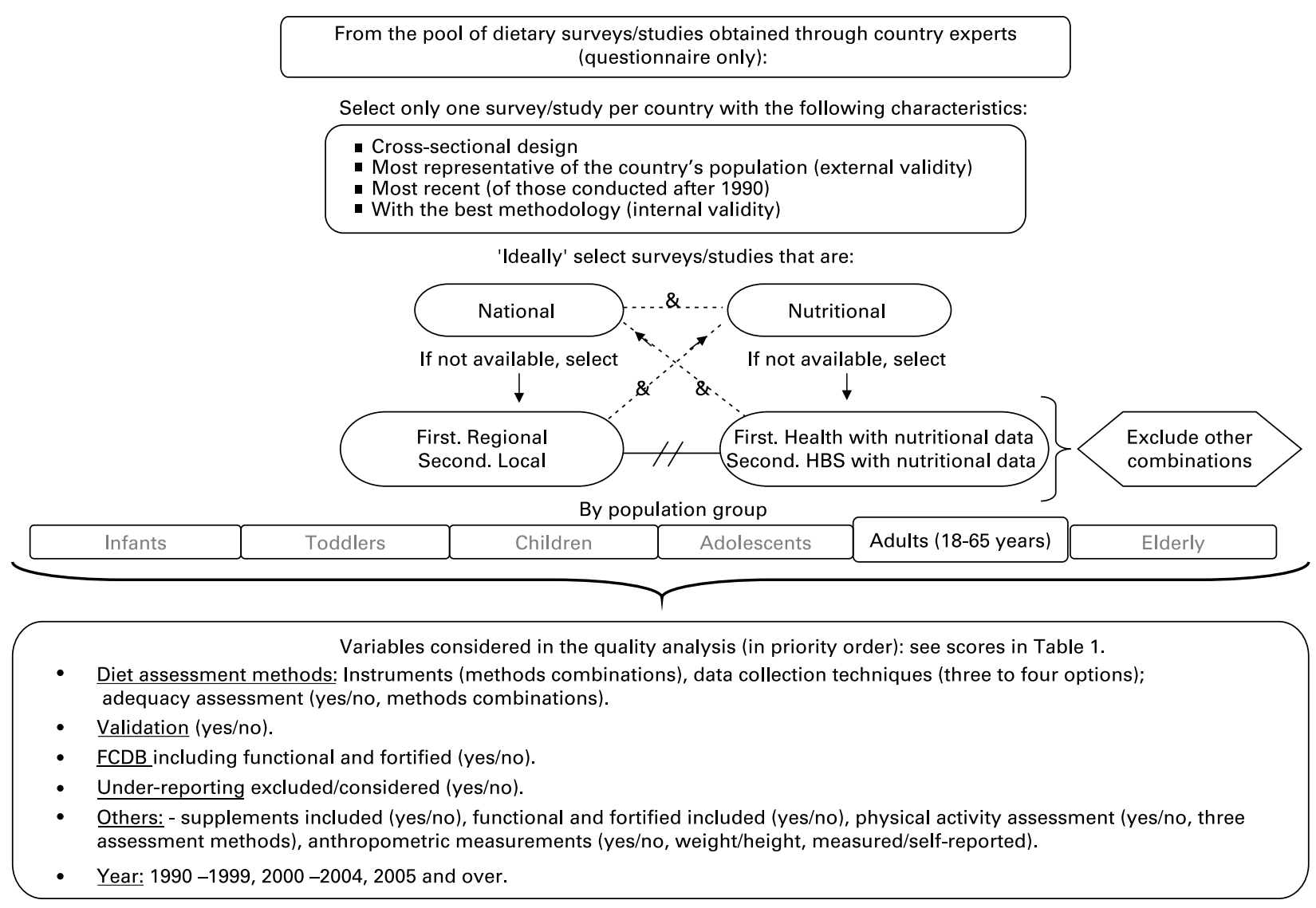

Fig. 1. The best-practice guide: how to select 'the best' dietary survey/study per country. HBS, Household Budget Survey, FCBD, Food Composition Database.

screening of the obtained information revealed that most countries (twenty-four out of thirty-two) had carried out surveys/studies on this population group and this age range was the widest, covering the majority of the population.

Once the best dietary surveys/studies per country were selected, they underwent a quality scoring test, whose results allowed us to rank the countries by the level of quality their surveys/studies obtained: high; medium; low. Fig. 1 shows the six variables and their subcategories that were considered for analysis in the scoring test, all extracted from the questionnaire's relevant questions. Pertinent variables and their scores in the scoring system were derived following consultation with EURRECA and external experts (Table 1).

It is worth mentioning that readers should be aware about the way these surveys/studies were referenced, since the references included might not respond to the 'official/definite' references. For example, in five cases, the respondent wrote: the survey/study 'has not been published yet' (Germany) or 'is in press' (Bulgaria) or 'its publication is in progress' (Austria) or 'no publication available as yet' (Lithuania). Such non-definite references were included in Table 2 as 'in the press' publications with one author only (facilitated by the questionnaire respondent), but they were excluded from the final reference section. The survey/study references of the final reference list have been written as provided by the respondent which, in some cases, included a web link.

\section{The 'quality scoring system'}

For the qualitative analysis, a 'quality scoring system' was developed using the answers to fifteen questions of the questionnaire completed by the country experts. Answers to these fifteen questions contained the information for creating the six quality variables and had been previously chosen upon consultation with EURRECA experts. Table 1 shows the variables or factors included, displayed into levels and sublevels, as well as their weights and scores/points distribution. Weights were allocated according to a variable priority order also agreed upon in consultation with EURRECA and external experts. Each answer regarding a survey/study characteristic was given a score, all scores were summed up and total scores (150 being the minimum and 1000 the maximum possible total values) compared across countries. Total scores (of three digits) were divided by 100, rounded up and truncated to one decimal for a clearer presentation. Unanswered questions were initially given the minimum score value possible - which was zero in many cases; however, at a second stage of the analysis (see 'Qualitative results') and in order to ameliorate misclassification and close the gaps between countries with complete and those with incomplete questionnaires, unanswered questions were given the maximum score value. This helped to simulate the maximum score that would have been reached by the country if all questions had been answered, which allowed the opportunity of a more realistic comparison subsequently carried out. 
Table 1. Quality scoring system: factors (F; with levels (L) and sublevels (S)), their weights and scores, by country survey/study

\begin{tabular}{|c|c|c|c|}
\hline Factors displaying levels and sublevels & $\begin{array}{l}\text { Weights } \\
100 \% \text { divided by six factors }\end{array}$ & $\begin{array}{l}\text { Scores (points) } \\
100 \%=1000 \text { points }\end{array}$ & Country $1,2, \ldots, X$ \\
\hline F1. Scope and type of surveys & $20 \%$ & 200 points $/$ by five levels $=40$ & \\
\hline L5. National and nutritional (the highest) & & $40 \times 5=200(\max )$ & \\
\hline L4. Regional and nutritional & & $40 \times 4=160$ & \\
\hline L3. Local and nutritional & & $40 \times 3=120$ & \\
\hline L2. National and health with nut. info. & & $40 \times 2=80$ & \\
\hline $\begin{array}{l}\text { L1. National and HBS with nut. info. } \\
\text { (the lowest) }\end{array}$ & & $40 \times 1=40(\min )$ & \\
\hline F2. Dietary assessment methods & $25 \% / 5$ levels $=5 \%$ & $250 /$ five sublevels $=50$ & \\
\hline L1. Instruments & $5 \%$ & $50 /$ four sublevels $=12.5$ & \\
\hline S4. R24 hr Rcl & & $10 \times 4=40(\max )$ & \\
\hline S3. S24 hr Rcl & & $10 \times 3=37.5$ & \\
\hline S2. EFR or WFR & & $10 \times 2=25$ & \\
\hline S1. FFQ & & $10 \times 1=12.5(\min )$ & \\
\hline $\mathrm{S} 2 / 3 / 4$. Recall and record combinations & & $10 \times 2 / 3 / 4$ (choose the highest used) & \\
\hline $\mathrm{S} 1 / 4 . \mathrm{FFQ}$ and $\mathrm{R} 24 \mathrm{hr} \mathrm{Rcl}$ & & $10 \times 1 / 4$ (choose the highest used) & \\
\hline $\mathrm{S} 1 / 3 . \mathrm{FFQ}$ and S24 $\mathrm{hr} \mathrm{Rcl}$ & & $10 \times 1 / 3$ (choose the highest used) & \\
\hline $\begin{array}{l}S 1 / 2 / 3 / 4 . F F Q \text { and recall and } \\
\text { record combinations }\end{array}$ & & $10 \times 1 / 2 / 3 / 4$ (choose the highest used) & \\
\hline L2. Data collection techniques & $5 \%$ & $50 / 3$ sublevels $=16.66$ & \\
\hline S3. Personal interview & & $16.66 \times 3=50(\max )$ & \\
\hline S2. Telephone interview & & $16.66 \times 2=33.20$ & \\
\hline S1. Self-administered questionnaire & & $16.66 \times 1=16.66(\min )$ & \\
\hline Combinations (choose the highest) $S 1 / 2 / 3$ & & $16.66 \times 1 / 2 / 3$ & \\
\hline L3. Nutrient Intake Adequacy (NIA) assessment & $5 \%$ & $50 /$ four sublevels $=12.5$ & \\
\hline \multicolumn{4}{|l|}{ Yes - methods } \\
\hline $\begin{array}{l}\text { S4. PA, or PA and biomarkers or } \\
\text { PA and others }\end{array}$ & & $12.5 \times 4=50(\max )$ & \\
\hline S3. Biomarkers and others & & $12.5 \times 3=37.5$ & \\
\hline S2. EAR/RDA and others & & $12.5 \times 2=25$ & \\
\hline S1. Others & & $12.5 \times 1=12.5$ & \\
\hline So. No & & $8.33 \times 0=0(\min )$ & \\
\hline L4. Could NIA be assessed? & $5 \%$ & 50 & \\
\hline S1. Yes & & $50 \times 1=50(\max )$ & \\
\hline So. No & & 0 (min) & \\
\hline L5. Validation & $5 \%$ & 50 & \\
\hline S1. Yes & & 50 (max) & \\
\hline So. No & & $0(\min )$ & \\
\hline F3. Food composition database & $20 \%$ & 200 & \\
\hline \multicolumn{4}{|l|}{ L1. Include functional and fortified foods } \\
\hline S1. Yes & & 200 (max) & \\
\hline So. No & & $0(\min )$ & \\
\hline F4. Mis-reporting & $15 \%$ & $150 / 2=75$ & \\
\hline \multicolumn{4}{|l|}{ L1. Under-reporting } \\
\hline S2. Excluded & & $75 \times 2=150(\max )$ & \\
\hline S1. Considered & & $75 \times 1=75(\min )$ & \\
\hline F5. Others & $5 \%$ & $50 / 4=12 \cdot 5$ & \\
\hline L1. Supplements included & $1.25 \% / 2=0.625 \%$ & $12 \cdot 5 / 2=6 \cdot 25$ & \\
\hline $\begin{array}{l}\text { S1. Vits and mins - yes and/or } \\
\text { dietary supplements - yes }\end{array}$ & & $6.25 \times 1$ or $6.25 \times 2$ (if both 'yes') & \\
\hline So. No & & $0(\min )$ & \\
\hline $\begin{array}{l}\text { L2. Functional and fortified included } \\
\text { (in the survey) }\end{array}$ & $1.25 \%$ & 12.5 & \\
\hline S1. Yes & & $12.5(\max )$ & \\
\hline So. No & & $0(\min )$ & \\
\hline L3. Physical activity assessed & $1.25 \%$ & $12 \cdot 5 / 5=2 \cdot 5$ & \\
\hline \multicolumn{4}{|l|}{ Yes - methods } \\
\hline S5. Accelerometer and questionnaire & & $2.5 \times 5=12.5(\max )$ & \\
\hline S4. Accelerometer & & $2.5 \times 4=10$ & \\
\hline S3. Questionnaire and pedometer & & $2.5 \times 3=7.5$ & \\
\hline S2. Questionnaire & & $2.5 \times 2=5$ & \\
\hline S1. Pedometer and other & & $2.5 \times 1=2.5$ & \\
\hline No & & $0(\min )$ & \\
\hline L4. Anthropometric measurements included & $1.25 \%$ & $12 \cdot 5 / 2=6 \cdot 25$ & \\
\hline \multicolumn{4}{|l|}{ Yes - specify } \\
\hline S2. Body weight and height - measured & & $6.25 \times 2=12.5(\max )$ & \\
\hline S1. Body weight and height - self-reported & & $6.5 \times 1=6.25$ & \\
\hline No & & 0 (min) & \\
\hline F6. Year & $5 \%$ & $50 / 2=25$ & \\
\hline L1. Last year of conduction period & $2.5 \%$ & $25 / 3=8 \cdot 33$ & \\
\hline
\end{tabular}


Table 1. Continued

\begin{tabular}{lll}
\hline Factors displaying levels and sublevels & $\begin{array}{l}\text { Weights } \\
100 \% \text { divided by six factors }\end{array}$ & $\begin{array}{l}\text { Scores (points) } \\
100 \%=1000 \text { points }\end{array}$ \\
\hline S3. 2005 and over & & $8.33 \times 3=25$ (max) \\
S2. $2000-4$ & & $8.33 \times 2=16 \cdot 66$ \\
S1. $1990-9$ & $2.5 \%$ & $8.33 \times 1=8.33(\min )$ \\
L2. Publication & & $25 / 2=12.5$ \\
S2. Published & $12.5 \times 2=25$ (max) \\
S1. In press & $12.5 \times 1=12.5$ \\
SO. Not published & 0 (min) \\
Total score &
\end{tabular}

HBS, Household Budget Survey; R-24-hr Rcl, repeated 24-hr recall; S-24-hr Rcl, single 24-hr recall; EFR, estimated food records; WFR, weighed food records; FFQ, food frequency questionnaire; PA, probabilistic approach; EARs/RDAs, Estimated Average Requirement/Recommended Dietary Allowances.

In this line, the higher the number of unanswered questions from a country, the greater the increase in its simulated scoring. Finally, the chosen best survey/study in each country was always the one scoring the highest. An index was used to classify countries into those having 'high' (score $>7$ ), 'medium' (score 4-7) and 'low' (score <4) information quality.

\section{Results}

Twenty-nine out of thirty-two countries responded to the questionnaire (response rate $92.2 \%$ ), sending a total of seventy-eight completed questionnaires (no questionnaires were received from Liechtenstein, Luxembourg or Slovakia, despite the three request reminders). The surveys/studies contained in the 'Country information found' table were then compared with those received as completed questionnaires and duplicates were eliminated. A final table containing 118 surveys/studies (forty plus seventy-eight) from all thirty-two countries was compiled, which was used for the counting and analysis of the results and for obtaining quantitative and qualitative results. As mentioned earlier, for the purpose of the present paper, only national cross-sectional surveys/studies on the adult population were considered in the analysis, representing a total of twenty-four.

\section{Quantitative results}

Experts from twenty-nine countries completed and sent their questionnaires; however, no national cross-sectional nutritional/health/household budget surveys/studies on adults were obtained from the following five countries: Cyprus - the experts sent completed questionnaires on two national surveys on children; Greece - sent questionnaires on one national survey on adults, but it was of 'cross-sectional within a cohort' design (European Prospective Investigation into Cancer and Nutrition - Greek component, 1994-9) ${ }^{(14)}$; Latvia - sent a questionnaire on one survey that was planned to be conducted in 2008, 'under national discussion' (First National Food Consumption Survey (7-64 years); Romania - sent one questionnaire on a national survey on the elderly ('Aging and Nutrition Project, Nutritional status in elderly-Romania' 2003 - official reference omitted by the expert); Switzerland - the expert sent a questionnaire on a local nutritional survey on adults from Geneva ${ }^{(15,16)}$. These five countries were therefore excluded from Table 2 'Methodological aspects of the twenty-four surveys/studies included in the analysis'. Table 2 shows that twenty-two out of twenty-four countries had carried out nutritional surveys/ studies at a national level, while two countries (Malta and Portugal) had national health surveys with nutritional data. Fifteen countries had conducted their surveys/studies since 2000 (five since 2005). The samples of all surveys/studies were representative of their countries' population, and only four out of twenty-four had a sample size below 900 subjects (Table 2). In terms of the methods for data collection, eleven countries used only personal interviews, one only telephone interviews, six only self-administered questionnaires, and six used combinations of two or three of the dietary techniques (Fig. 2). Regarding dietary instruments, two countries used only repeated $24 \mathrm{~h}$ recalls, three countries used only a single $24 \mathrm{~h}$ recall, eight used only estimated and/or weighed food records (one used dietary history), three used only FFQ (one used only specific questions - Portugal), eight used combinations of recalls, records and FFQ (two also used dietary histories) (Fig. 3). As per the NIA method, twelve countries used only comparison with estimated average requirements/RDA, two used only the probabilistic approach and standard deviation/Z-scores, five used combinations of comparisons to estimated average requirements/RDA and other methods: one with probabilistic approach, one with nutrition quality index, one with biomarkers of status, one with Mediterranean adequacy index, and one with probabilistic approach, nutrition quality index and nutrition adequacy ratio; in addition, three surveys/studies did not assess NIA and two left this question unanswered (Fig. 4).

\section{Qualitative results: country ranking}

Fig. 5 shows that nine out of twenty-four countries (37.5\%) have surveys/studies with high information quality, twelve (50.0\%) have medium information quality surveys/studies, and three $(12.5 \%)$ have low information quality. It can also be observed that, considering the answers by the experts to all relevant questions, the country that obtains the highest score is France $(8 \cdot 1)$, closely followed by Finland, Lithuania and Spain (8.0).

Fig. 5 also shows six countries whose questionnaires were incomplete, which brought their scoring down to unrealistic figures in some cases (unanswered questions scored the minimum score value). However, Fig. 6 shows that, through the simulated scoring, countries like The Netherlands, Germany and the United Kingdom can substantially increase their scores to a more realistic present picture of the quality of existing/available/accessible information. Nevertheless, the results from these three countries do reflect the lower level of involvement from the experts to whom the questionnaire was sent. 


\begin{tabular}{|c|c|c|c|c|c|c|c|}
\hline No. & Country* & Fieldwork & $\begin{array}{l}\text { Age (years), sample size (n) and sex } \\
(M-F)\end{array}$ & $\begin{array}{l}\text { Dietary } \\
\text { data } \\
\text { collection } \\
\text { techniques }\end{array}$ & $\begin{array}{l}\text { Dietary } \\
\text { instruments }\end{array}$ & $\begin{array}{l}\text { Nutrient intake adequacy } \\
\text { assessment methods }\end{array}$ & Reference (Study Director and survey name) \\
\hline 1 & Austria & $2005-6$ & $18-65(n 1103 \mathrm{M}$ and $1655 \mathrm{~F})$ & $S A Q$ & $\mathrm{~S} 24 \mathrm{hr} \mathrm{Rcl}$ & Comparison with EAR/RDA & $\begin{array}{l}\text { Elmadfa et al. Austrian Study on Nutritional } \\
\text { Status (ASNS) (In the Press). }\end{array}$ \\
\hline 2 & Belgium & $2004-5$ & $\begin{array}{l}15-18,19-29,30-59,60-74,75+ \\
\quad(n 1546 \mathrm{M} \text { and } 1537 \mathrm{~F})\end{array}$ & PI & $\mathrm{R} 24 \mathrm{hr} \mathrm{Rcl}$ & Comparison with EAR/RDA & $\begin{array}{l}\text { De Vriese et al. }{ }^{(29)} \text { Belgian national food con- } \\
\text { sumption survey in the adult population } \\
\text { (15 years and older). }\end{array}$ \\
\hline 3 & Bulgaria & $\begin{array}{l}\text { March-April } \\
2004\end{array}$ & $\begin{array}{l}1-2,3-6,7-9,10-13,14-18,19-29 \\
30-59,60-74,75+(n 1113 \\
\text { and } 1142 \mathrm{~F})\end{array}$ & PI & $\begin{array}{r}\mathrm{S} 24 \mathrm{hr} \mathrm{Rcl} \\
\text { and FFQ }\end{array}$ & $\begin{array}{l}\text { PA and standard deviation/ } \\
Z \text {-scores }\end{array}$ & $\begin{array}{l}\text { Baykova et al. }{ }^{(30)} \text { National monitoring of } \\
\text { dietary intake and nutritional status of } \\
\text { Bulgaria population } 2004 .\end{array}$ \\
\hline 4 & $\begin{array}{l}\text { Czech } \\
\text { Republic }\end{array}$ & $2003-4$ & $\begin{array}{l}4-6,7-10,11-14,15-17,18-59 \\
60+(n 1235 \mathrm{M} \text { and } 1365 \mathrm{~F})\end{array}$ & PI & $\begin{array}{r}\mathrm{R} 24 \mathrm{hr} \mathrm{Rcl} \\
\text { and FFQ }\end{array}$ & $\begin{array}{l}\text { Usual intake with probabilistic } \\
\text { uncertainty analysis }\end{array}$ & $\begin{array}{l}\text { Ruprich et al. }{ }^{(31)} \text { Study of individual food } \\
\text { consumption (SISP04). }\end{array}$ \\
\hline 5 & Denmark & $2000-2$ & $\begin{array}{l}4-5,6-9,10-17,18-24,25-34 \\
35-44,45-54,55-64,66-75 \text { (n } 1954 \\
M \text { and } 2166 \mathrm{~F})\end{array}$ & $\begin{array}{r}\mathrm{PI} \text { and } \\
\text { SAQ }\end{array}$ & EFR & $\begin{array}{l}\text { Comparison with Nordic } \\
\text { nutrition recommendations }\end{array}$ & $\begin{array}{l}\text { Lyhne et al. }{ }^{(32)} \text { The Danish National Survey } \\
\text { of Dietary Habits and Physical Activity. } \\
\text { (Dietary Habits in Denmark 2000-2). }\end{array}$ \\
\hline 6 & Estonia & $1997-7$ & $\begin{array}{l}19-34,35-49,50+(n 902 \mathrm{M} \text { and } \\
1115 \mathrm{~F})\end{array}$ & PI & $\begin{array}{l}\mathrm{S} 24 \mathrm{hr} \mathrm{Rcl} \\
\text { and FFQ }\end{array}$ & Comparison with EAR/RDA & $\begin{array}{l}\text { Pomerleau et al. }{ }^{(33,34)} \text { Estonian Adults } \\
\text { Nutrition Survey. }\end{array}$ \\
\hline 7 & Finland & $\begin{array}{l}\text { January-April } \\
\quad 2002\end{array}$ & $\begin{array}{l}25-34,35-44,45-54,55-64,65-74 \\
\text { (in two areas) ( } n 915 \mathrm{M} \text { and } 1095 \mathrm{~F})\end{array}$ & $\begin{array}{r}\mathrm{PI} \text { and } \\
\text { SAQ }\end{array}$ & $\begin{array}{r}\mathrm{R} 24 \mathrm{hr} \mathrm{Rcl} \\
\text { and EFR }\end{array}$ & $\begin{array}{l}\text { PA and comparison with } \\
\text { EAR/RDA (comparison } \\
\text { with the Finnish nutrition } \\
\text { recommendations) }\end{array}$ & $\begin{array}{l}\text { Männistö et al. }{ }^{(35)} \text { The National FINDIET } \\
2002 \text { Study ('carried out in a subsample of } \\
\text { the National FINRISK } 2002 \text { Study', by } \\
\text { Laatikainen et al.). }\end{array}$ \\
\hline 8 & France & $2006-7$ & $\begin{array}{l}3-10,11-14,15-17,18-29,30-54 \\
55-74(n 1959 \mathrm{M} \text { and } 2830 \mathrm{~F})\end{array}$ & $\mathrm{PI}$ and $\mathrm{TI}$ & $\mathrm{R} 24 \mathrm{hr} \mathrm{Rcl}$ & $\begin{array}{l}\text { Comparison with EAR/RDA } \\
\text { and NQI }\end{array}$ & $\begin{array}{l}\text { Castetbon \& Hercberg }{ }^{(36)} \text {. Etude Nationale } \\
\text { Nutrition Santé (ENNS). }\end{array}$ \\
\hline 9 & Germany & $2005-7$ & $14-80(n$ about 20000$)$ & $\begin{array}{l}\mathrm{PI}, \mathrm{TI} \text { and } \\
\text { SAQ }\end{array}$ & $\begin{array}{l}\mathrm{R} 24 \mathrm{hr} \text { Rcl, } \\
\text { WFR } \\
\text { and DH }\end{array}$ & Left 'blank' & Brombach et al. ${ }^{(37)}$ National Nutrition Survey II. \\
\hline 10 & Hungary & $\begin{array}{l}\text { November- } \\
\text { December } \\
2003\end{array}$ & $19-34,35-59,60+(n 473 \mathrm{M}$ and $706 \mathrm{~F})$ & $\begin{array}{r}\mathrm{PI} \text { and } \\
\text { SAQ }\end{array}$ & EFR & $\begin{array}{l}\text { Comparison with EAR/RDA } \\
\text { (comparison with Hungarian } \\
\text { RDI) }\end{array}$ & $\begin{array}{l}\text { Biró et al. }{ }^{(38)} \text { Third National Nutrition Survey } \\
\text { ('a part of the National Health Survey of } \\
\text { the Population - OLEF 2003', by Stehle } \\
\text { et al.). }\end{array}$ \\
\hline 11 & Iceland & $\begin{array}{l}\text { May-November } \\
2002\end{array}$ & $\begin{array}{l}15-19,20-39,40-59,60-80(n 580 \mathrm{M} \\
\text { and } 662 \mathrm{~F})\end{array}$ & $\mathrm{TI}$ & $\mathrm{S} 24 \mathrm{hr} \mathrm{Rcl}$ & $\begin{array}{l}\text { Comparison with EAR/RDA } \\
\text { (comparison with RDA) }\end{array}$ & $\begin{array}{l}\text { Steingrímsdóttir et al. }{ }^{(39)} \text { The Diet of } \\
\text { Icelanders, Dietary Survey of The Icelandic } \\
\text { Nutrition Council 2002, Main Findings. }\end{array}$ \\
\hline 12 & Ireland & $1997-9$ & $\begin{array}{l}18-35,36-50,51-64(n 662 \mathrm{M} \\
\quad \text { and } 717 \mathrm{~F})\end{array}$ & $S A Q$ & $\begin{array}{l}\text { WFR or } \\
\text { EFR } \\
\text { (7-d food } \\
\text { diary) }\end{array}$ & $\begin{array}{l}\text { Biomarkers of status and } \\
\text { comparison with EAR/RDA }\end{array}$ & $\begin{array}{l}\text { Kiely }{ }^{(40)} \text { North/South Ireland Food } \\
\text { Consumption Survey } 2001 \text { - by IUNA } \\
\text { (Irish Universities Nutrition Alliance). }\end{array}$ \\
\hline 13 & Italy & $2005-6$ & $\begin{array}{l}\text { All members in each selected household } \\
\text { (cluster): } 0-2 \cdot 9 ; 3-9 \cdot 9 ; 10-17 \cdot 9 \text {; } \\
\text { 18-64.9; } 65+(n 1501 \mathrm{M} \text { and } 1821 \mathrm{~F})\end{array}$ & PI & EFR & $\begin{array}{l}\text { Comparison with EAR/RDA } \\
\text { and Mediterranean adequacy } \\
\text { index }\end{array}$ & $\begin{array}{l}\text { Turrini \& Leclercq }{ }^{(41)} \text { Food Consumption } \\
\text { Survey INRAN-SCAI 2005-6. }\end{array}$ \\
\hline 14 & Lithuania & April-June 2007 & $\begin{array}{l}16-64,19-34,35-49,50-64 \text { (initial } n \\
\text { 5000, between Lithuanians, Russians } \\
\text { and Polish) }\end{array}$ & $\mathrm{PI}$ & $\begin{array}{r}\mathrm{S} 24 \mathrm{hr} \mathrm{Rcl} \\
\text { and FFQ }\end{array}$ & Left 'blank' & $\begin{array}{l}\text { Barzda et al. Macronutrient, Food Intake and } \\
\text { Health Behavior in the Lithuanian } \\
\text { Population (In the Press). }\end{array}$ \\
\hline 15 & Malta & $2002-3$ & $\begin{array}{l}15-24,25-44,45-64,65-74,+75 \\
(n 5510,46 \cdot 88 \% \mathrm{M} \text { and } 52 \cdot 84 \% \mathrm{~F})\end{array}$ & $\begin{array}{r}\mathrm{PI} \text { and } \\
\mathrm{SAQ}\end{array}$ & FFQ & Not assessed & $\begin{array}{l}\text { Pace Asciak et al. }{ }^{(42)} \text { The First, National } \\
\text { Health Interview Survey (HIS Malta 2002). }\end{array}$ \\
\hline 16 & $\begin{array}{l}\text { The } \\
\text { Netherlands }\end{array}$ & $1997-8$ & $1-97(n 6250)$ & $\mathrm{SAQ}$ & $\begin{array}{l}\text { WFR and } \\
\text { DH }\end{array}$ & Comparison with EAR/RDA & $\begin{array}{l}\text { Anonymous }{ }^{(43)} \text {. Netherlands Nutrition Centre. } \\
\text { The third Dutch National Food Consump- } \\
\text { tion Survey (DNFCS-3). }\end{array}$ \\
\hline
\end{tabular}




\begin{tabular}{|c|c|c|c|c|c|c|c|}
\hline No. & Country* & Fieldwork & $\begin{array}{l}\text { Age (years), sample size (n) and sex } \\
(M-F)\end{array}$ & $\begin{array}{l}\text { Dietary } \\
\text { data } \\
\text { collection } \\
\text { techniques }\end{array}$ & $\begin{array}{l}\text { Dietary } \\
\text { instruments }\end{array}$ & $\begin{array}{l}\text { Nutrient intake adequacy } \\
\text { assessment methods }\end{array}$ & Reference (Study Director and survey name) \\
\hline 17 & Norway & $\begin{array}{l}\text { March, June, } \\
\text { September } \\
\text { and November } \\
-1997\end{array}$ & $\begin{array}{c}16-19,20-29,30-39,40-49,50-59 \\
60-69,70-79(n 1298 \mathrm{M} \text { and } 1374 \mathrm{~F})\end{array}$ & $S A Q$ & FFQ & Not assessed & Johansson \& Solvol ${ }^{(44)}$. NORKOST 2. \\
\hline 18 & Poland & $\begin{array}{l}\text { September- } \\
\text { November } \\
2000\end{array}$ & $\begin{array}{l}1-3,4-6,7-9,10-12,13-15,16-18 \\
19-25,26-60,60+(n 1911 \mathrm{M} \text { and } \\
2223 \mathrm{~F})\end{array}$ & PI & S24 hr Rcl & $\begin{array}{l}\text { Comparison with EAR/RDA } \\
(\% \text { RDA })\end{array}$ & $\begin{array}{l}\text { Szponar et al. }{ }^{\left({ }^{2} 5\right)} \text { 'Household food consump- } \\
\text { tion and anthropometric survey'. }\end{array}$ \\
\hline 19 & Portugal & $1998-9$ & $\begin{array}{l}0-4,5-14,15-24,25-34,35-44 \\
45-54(n 22408 \mathrm{M} \text { and } 24771 \mathrm{~F})\end{array}$ & $\mathrm{PI}$ & $\begin{array}{l}\text { FFQ with } \\
\text { 'Especi- } \\
\text { fic ques- } \\
\text { tions' }\end{array}$ & Not assessed & Graça et al. ${ }^{(46)}$ Inquérito Nacional de Saúde. \\
\hline 20 & Serbia & $\begin{array}{l}1997-8 \\
\text { (ten cities) }\end{array}$ & $19-65(n 1475 \mathrm{M}$ and 1632F) & $S A Q$ & $\begin{array}{l}\text { EFR and } \\
\text { WFR }\end{array}$ & Comparison with EAR/RDA & $\begin{array}{l}\text { Pavlović et al. }{ }^{(47,48)} \text { Nutrition as the potential } \\
\text { risk factor of atherosclerosis } \\
\text { (YUSAD study). }\end{array}$ \\
\hline 21 & Slovenia & 1995 & $\begin{array}{l}18-25,26-45,46-65 \text { ( } n 954 \mathrm{M} \text { and } \\
1229 \mathrm{~F})\end{array}$ & $\mathrm{PI}$ & $\begin{array}{r}\mathrm{S} 24 \mathrm{hr} \mathrm{Rcl} \\
\text { and FFQ }\end{array}$ & Comparison with EAR/RDA & $\begin{array}{l}\text { Koch \& Pokorn }{ }^{(49,50)} \text { Nutritional habits of } \\
\text { Slovenian adults in health protection } \\
\text { aspect. }\end{array}$ \\
\hline 22 & Spain & $1998-2000$ & $\begin{array}{l}2-5,6-9,10-13,14-17,18-24 \\
(n 1629 \mathrm{M} \text { and } 1905 \mathrm{~F})\end{array}$ & $\mathrm{PI}$ & $\begin{array}{r}\mathrm{R} 24 \mathrm{hr} \mathrm{Rcl} \\
\text { and FFQ }\end{array}$ & $\begin{array}{l}\text { Comparison with EAR/RDA } \\
(<1 / 3,<2 / 3,<\mathrm{RNI}), \mathrm{PA}, \\
\mathrm{NQI} \text { and nutrition adequacy } \\
\text { ratio }\end{array}$ & Serra Majem et al. ${ }^{(51)}$ EnKid Study. \\
\hline 23 & Sweden & $1997-8$ & $\begin{array}{l}18-24,25-34,35-44,45-54,55-64 \\
65-74(n 589 \mathrm{M} \text { and } 625 \mathrm{~F})\end{array}$ & SAQ & EFR & Comparison with EAR/RDA & Becker \& Pearson ${ }^{(52)}$ Riksmaten 1997-8. \\
\hline 24 & $\begin{array}{l}\text { United King- } \\
\text { dom }\end{array}$ & $2000-1$ & $\begin{array}{l}19-24,25-34,35-39,50-64 \\
\quad(n \text { approximately } 2000)\end{array}$ & PI & WFR & $\begin{array}{l}\text { Comparison with EAR/RDA } \\
\text { and RNV }\end{array}$ & $\begin{array}{l}\text { Henderson et al. }{ }^{(53-55)} \text {, Ruston et al. }{ }^{(56)} \text { and } \\
\text { Hoare et al. }{ }^{(57)} \text { National Dietary and } \\
\text { Nutritional Survey (NDNS) adults aged } \\
\text { 19-64. }\end{array}$ \\
\hline
\end{tabular}

SAQ, self-administered questionnaires; S24 hr Rcl, single $24 \mathrm{~h}$ recall; EAR, estimated average requirements; PI, personal interview; R24 hr Rcl, repeated $24 \mathrm{~h}$ recall; PA, probabilistic approach; EFR, estimated food records; $\mathrm{TI}$, telephone interview; NQI, nutrition quality index; WFR, weighed food records; DH, dietary history; RDI, recommended daily intake; RNI, recommended nutrient intake; RNV, relative nutritional values. * Countries that had expert response for which no national cross-sectional nutritional/health/HBS, household budget surveys/studies on adults were obtained: Cyprus; Greece; Latvia; Romania; Switzerland. 


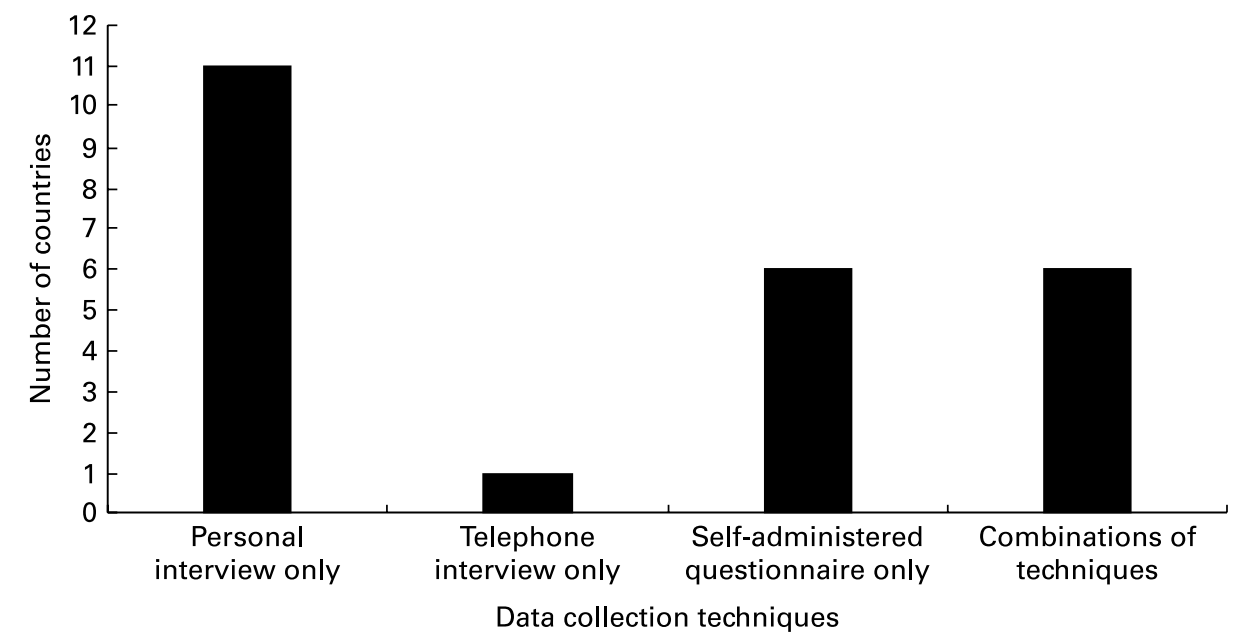

Fig. 2. Number of countries using the different data collection techniques.

Fig. 7 shows the rearrangement of scores including the simulated ones for the six countries previously discussed. A new country ranking can thus be observed: Lithuania and Spain reach the leading positions; The Netherlands, the United Kingdom and Germany are included in the high category; and Poland upgrades positions within the same category. Needless to say, the 'real' score of all these countries would be somewhere between the 'present' and the 'simulated' scores. The national health surveys from Malta and Portugal remain in the low category scoring $<4$.

\section{Discussion}

The format of the quantitative results on dietary data collection instruments allows comparison with those of the latest ENHRII $^{(8)}$, and it can be observed that the surveys/studies from the present work not only employed instruments separately (e.g. single $24 \mathrm{~h}$ recall only), but also combinations of different instruments (e.g. single $24 \mathrm{~h}$ recall and FFQ). We believe that analysing the methods employed in combination as opposed to separately gives a better reflection of reality, since that is how methods are usually found in studies. In addition, the number of 'partners' or 'countries' included in the analysis is also different, fifty-three 'partners' from the ENHRII as compared with the present study's twentyfour. It is interesting to point out that twelve out of fiftythree partners $(22.6 \%)$ of the ENHRII use single $24 \mathrm{~h}$ recalls as compared with the three in the present study (12.5\%); moreover, the highest difference is observed in FFQ use: seventeen ENHRII partners $(32.1 \%)$ and three identified by the present study $(12.5 \%)$. Expert consultation through a questionnaire yields comparable results across partners or countries, and using similar formats as those found in different European projects/studies facilitates comparison across them at a European level. Another relevant point is the fact that the ENHRII includes data on adults and children, which reinforces the possibility of carrying out the analysis on other population groups.

When comparing the results from Table 1 with those found by $\operatorname{EFCOSUM}^{(3)}$, it can be observed that, for Slovakia, the EFCOSUM publication shows the study 'Assessment of food habits and nutritional status ${ }^{(17,18)}$, on the population ranging 11-88 years; the present study could not be obtained through the country experts; hence, the country was not included in the analysis. On the contrary, Serbia was not included in the EFCOSUM review, while the national study

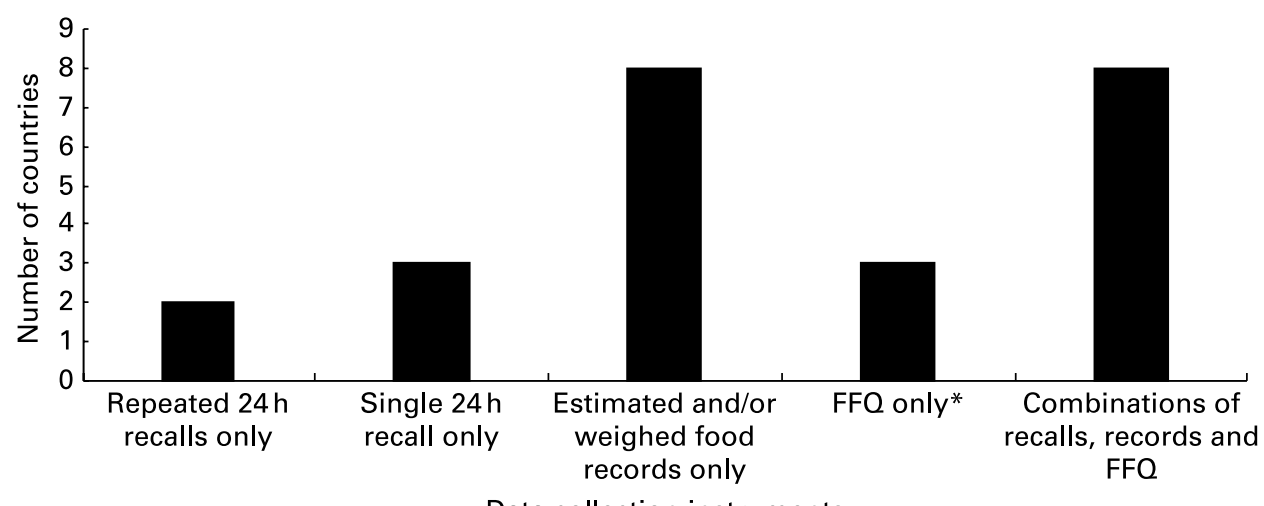

Data collection instruments

Fig. 3. Number of countries using the different data collection instruments. * One food frequency questionnaire of 'specific questions'. 


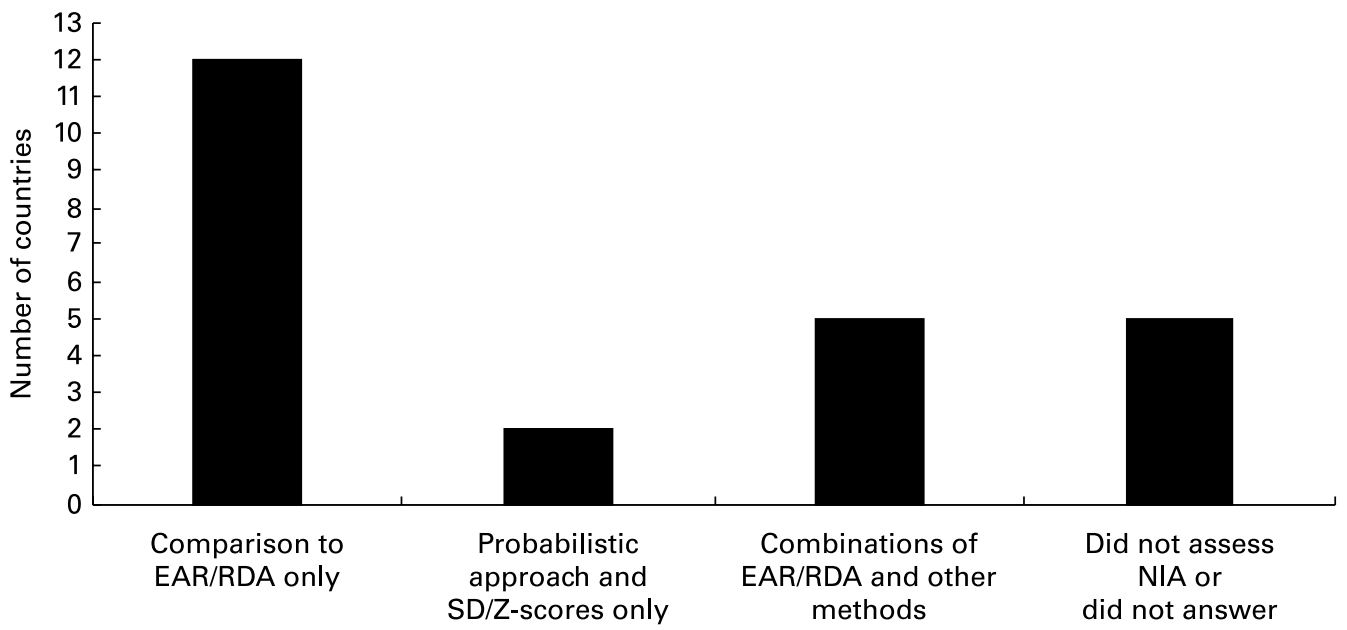

Nutrient intake adequacy (NIA) assessment methods

Fig. 4. Number of countries using the different NIA assessment methods. EAR, estimated average requirements; NIA, nutrient intake adequacy.

'Nutrition as the risk factor for atherosclerosis' has been included in the present analysis. In the case of Croatia, it was included in the EFCOSUM review but not in the present analysis. Finally, Liechtenstein and Luxembourg were not included either in the EFCOSUM review or in the present analysis; therefore, their nutrition information status in terms of intake methods remains unknown to us. Country inclusion/exclusion criteria should be further justified in future work within Europe, so that wider comparisons can be made.

The present study also includes national health surveys that contain nutritional data from Malta and Portugal. Although comparison of nutritional and health surveys is not ideal, because their methodology differs in concordance to their objectives, we believe that including national health surveys containing nutritional information from a given country not only allows the increase of knowledge about the information available, but also gives recognition to the work carried out in the country and the opportunity to be included in comparative descriptive studies within European projects such as EURRECA. Nevertheless, defining the criteria for the type and scope of studies to be included is also important.

We would also like to acknowledge the countries that were not included in the analysis because no national nutritional survey/study was obtained through the questionnaire, but whose experts did send questionnaires on adult studies of regional or local scope. This is the case for regional surveys from Greece - the 'Nutritional survey of the province of Attica (The ATTICA Study 2001-2002) ${ }^{(19)}$, and Romania the 'Nutritional survey of Transylvania $(2002-2004)^{(20)}$, At the local level, Portugal has the "Health study considering food habits in Porto (The EPIPorto Study 1999-2003) ${ }^{(21)}$, and Switzerland the 'Nutritional and physical health survey, Geneva (The Bus Santé Study 1993-2008, every

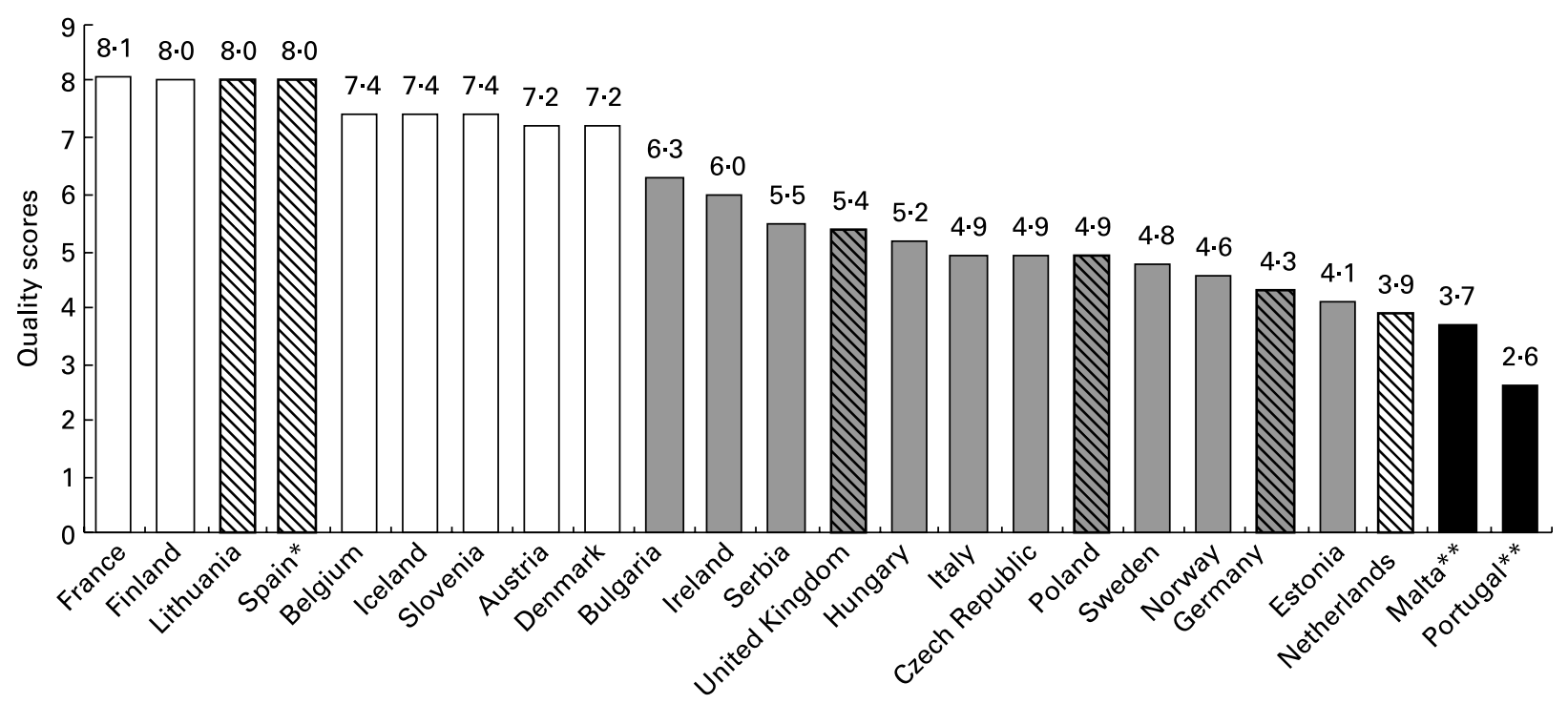

Fig. 5. Countries with 'high', 'medium' and 'low' information quality from their national surveys/studies on adults (18-65 years) - present scores showing countries with complete and incomplete questionnaires. $\square$, 'high' information quality (score >7); $\square$, medium information quality (scores 4-7); $\square$, low information quality $($ score $<4) ; \mathbb{N}$, countries with incomplete questionnaires. ${ }^{*}$ The survey includes young adults only (18-24 years). ${ }^{\star \star}$ National health surveys containing nutritional data. 


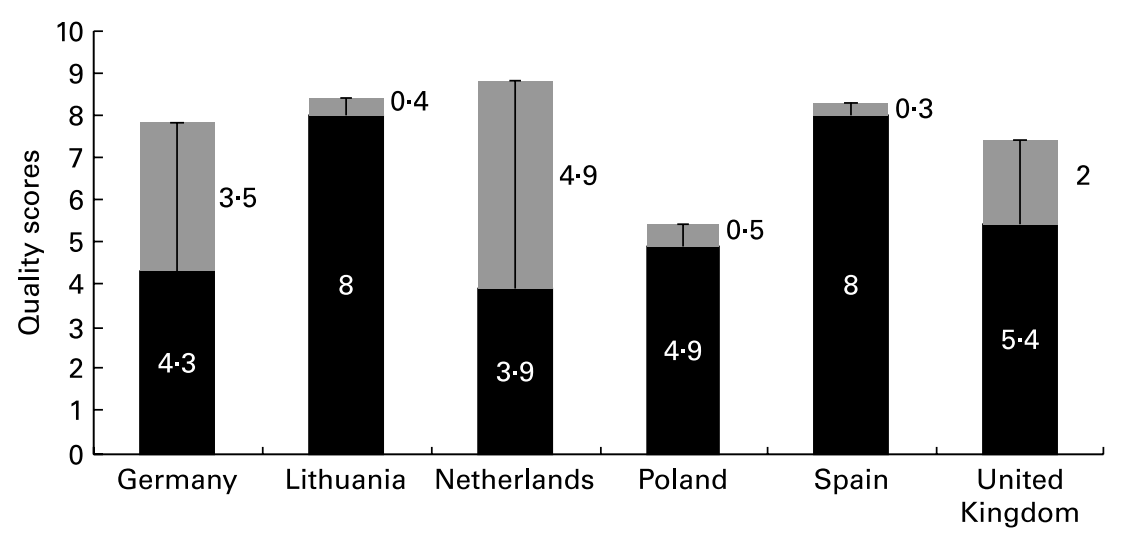

Fig. 6. The present and simulated scores of countries with incomplete questionnaires. $\square$, simulated score: current score + maximum score from unanswered questions; $\square$, current score: missing scores from unanswered questions.

year $^{(15,16)}$, Had the inclusion criteria been different, emphasising other aspects of the surveys different from their national scope, these countries probably would have been included. On the contrary, in the case of Spain whose score was high, its survey benefited from the national scope criterion. However, if the objective had been to cover as much of the population as possible, this survey would have been in a weaker position, as it only included the youngest adult population (aged 18-24 years). There were several Spanish regional nutritional surveys that covered the adult population range (18-65 years) that had been excluded and for which experts had also sent questionnaires ('Evaluation of the Nutritional Status of the Catalan Population' - ENCAT survey 2002-3) ${ }^{(22)}$, ('Nutritional Survey of The Canary Islands' - ENCA 1997-8) ${ }^{(23,24)}$, ('Nutritional Survey of The Balearic Islands' ENIB 1999-2000) ${ }^{(25)}$, 'Nutrition and Health Survey of the Community of Valencia 1994') ${ }^{(26)}$. Finally, it must be taken into account that in the case of The Netherlands and the United Kingdom, with present scores of 3.9 and 5.4, respectively, the questionnaire was completed by the authors of the present study using the information found in the different literature searches, as no questionnaire was completed by any expert on these national nutritional surveys on adults (Table 1). As such, we emphasise the relevance of selecting adequate experts when results depend on their response.

The results presented earlier meet the objective of applying an information search strategy that combines internet and available written literature with the collection of existing data by means of a designed questionnaire ${ }^{(13)}$. However, there are several points that should be further discussed before drawing conclusions and recommendations based on the results obtained. Blanquer et al. have recommended a combination of both approaches of the strategy to obtain information in order to derive more complete results. Nevertheless, the questionnaire was chosen for the present paper's analysis because it was thought that using a specific format would restrict the possibilities of data presentation, which would then ease subsequent comparison of the information. Having gone through the experience, we can now identify the advantages and limitations of the procedures followed:

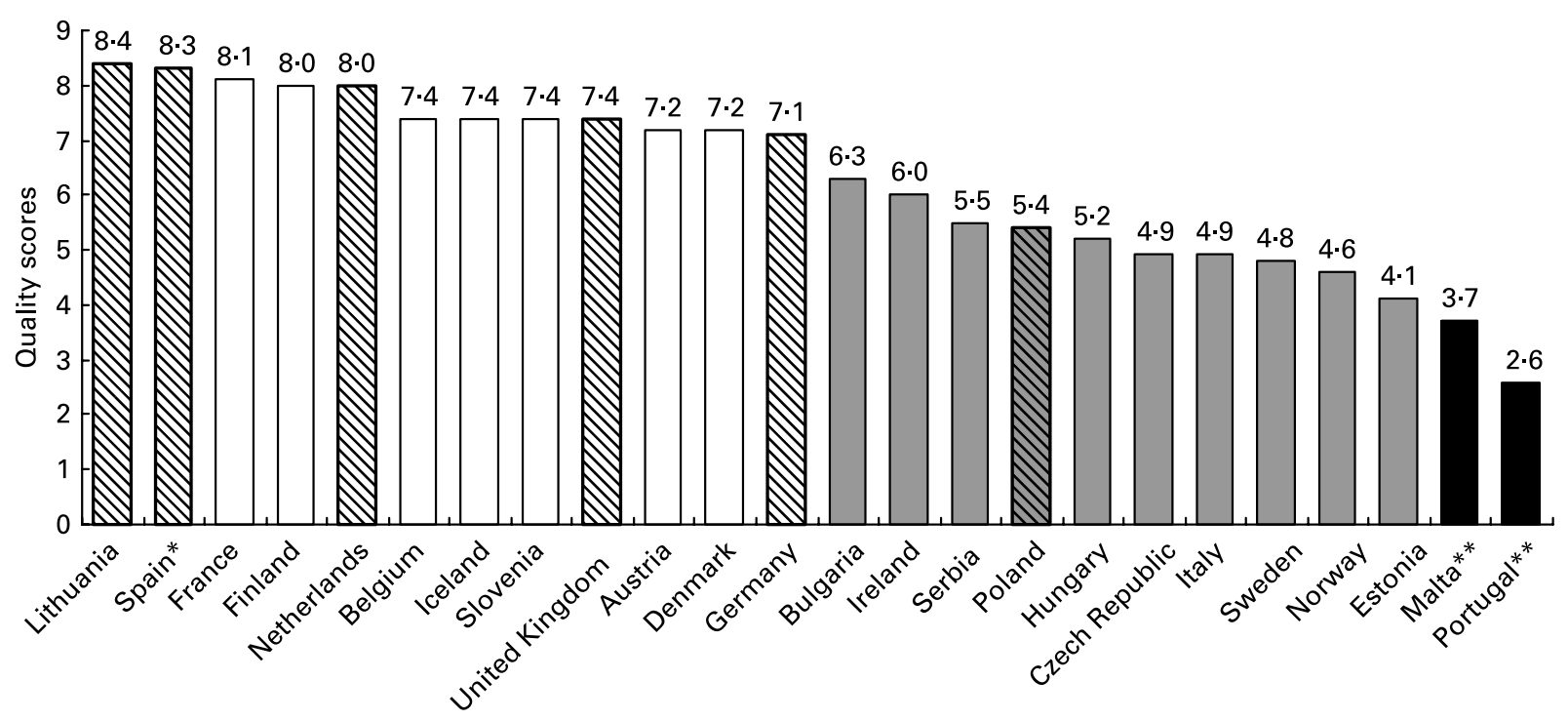

Fig. 7. Countries with 'high', 'medium' and 'low' information quality including simulated scores of countries with incomplete questionnaires: national surveys/studies on adults (18-65 years). $\square$, 'high' information quality (score $>7$ ); $\square$, medium information quality (scores $4-7$ ); $\square$, low information quality (score <4); $\mathbb{N}$, adjusted by simulation. * The survey includes young adults only (18-24 years). ${ }^{* *}$ National health surveys containing nutritional data. 
1. Countries varied in their definitions of age groups, and hence we had great difficulty when classifying the surveys/studies by population group, before limiting the analysis only to adults. A clear definition of age ranges at early stages of EURRECA would have been time-saving and would have reinforced objectivity and consistency of results. Potential misclassification could therefore be reduced.

2. Using expert knowledge to complete questionnaires can expedite the information collecting process, but it can also introduce bias if the experts have not thoroughly completed the questions, due to a diverse spectrum of reasons: under-reporting as a result of lack of time; knowledge ('indirect or not real experts'); interest or understanding of the question; over-reporting due to, e.g. excessive interest for their country/study to perform well. Taking this into account, some questions of the questionnaire used could be identified as 'problematic' because of the low response rate, seen in particular with those addressing nutrients considered in the survey/study (but not included in the present analysis), those related to NIA assessment methods or those that asked for a survey/study reference. Regarding NIA assessment methods in particular, and based on the experience from this work, we would like to recommend future researchers to separate questions on estimated average requirements from questions on RDA or from questions on any other reference value e.g. Lower Nutrient Reference Level, etc. This will allow for the identification of the exact reference value used by each survey/ study and whether or not it is appropriate, according to present recommendations ${ }^{(27,28)}$.

All these, among other issues, can distort the final results and make us draw an unrealistic picture of the situation. We therefore recommend that the data collection strategy be as objective as possible to assure that the results obtained are the most reliable.

We conclude that the present research, performed as part of the EURRECA Network of Excellence, represents an attempt at designing a strategy for identifying cross-sectional nutritional data at the individual level and testing developed innovative tools for data quality analysis. Although there is room for improvement and caution should be taken when drawing conclusions and recommendations from these results, the lessons learned and tools developed help set the context for future analysis and evaluation within the EURRECA framework for aligning European micronutrient recommendations.

\section{Acknowledgements}

The study reported herein has been carried out within the EURRECA Network of Excellence (www.eurreca.org), financially supported by the Commission of the European Communities, specific Research, Technology and Development Programme Quality of Life and Management of Living Resources, within the Sixth Framework Programme, contract no. 036196. The present report does not necessarily reflect the Commission's views or its future policy in this area. A. G.-A. developed and carried out the search strategy, undertook analysis and wrote the first draft of the paper. M. B. developed and carried out the search strategy, contributed to writing of first draft and commented on following drafts of the paper. L. R.-B. participated in the planning of the strategy, supervised the work and commented on drafts of the paper. T. M. A. W. participated in the planning of the strategy developed and commented on drafts of the paper. G. T. participated in the planning of the strategy and commented on drafts of the paper. M. G. participated in the planning of the strategy and commented on drafts of the paper. L. S.-M. participated in the planning of the strategy, directed and supervised the work and commented on all drafts of the paper. The authors would like to thank the following persons for their interest shown in our work and the effort made when completing questionnaires and exchanging correspondence to 'fill in the gaps': Elmadfa I; Freisling H (Department of Nutr Sciences, University of Vienna, - Austria); Van Oyen $\mathrm{H}$; Vandevijvere S (Scientific Institute of Public Health Belgium); Angelova KC (National Center of Public Health Protection - Bulgaria); Panagiotakos DB; Polychronopoulos EA (Harokopio University - Cyprus); Lazarou C (Harokopio University - Cyprus); Jiri Ruprich (National Institute of Public Health - Czech Republic); Groth M (National Food Institute - Denmark); Vaask S (University of Technology Estonia); Valsta L; Vartiainen E; Laatikainen T (National Public Health Institute - Finland); Hercberg S; Castetbon K (Institut de veille Sanitaire - France); Kersting M (Research Institute of Child Nutrition Dortmund - Germany); Krems C (Federal Research Institute for Nutrition - Germany); Roma-Giannikou E; Manios Y; Benetou V; Trichopoulou A (University of Athens - Greece); Gabor Z (National Public Health and Medical Officer Service (Állami Népegészségügyi és Tisztiorvosi Szolgálat) - Hungary); Jonsdottir E; Thorsdottir I (University Hospital - Iceland); Steingrímsdóttir L; Porgeirsdóttir H (Public Health Institute of Iceland - Iceland); Wall P; Gibney M (Trinity College Dublin, University College Cork - Ireland; University of Ulster - Northern Ireland); D’Amicis A; Cialfa E; Turín A; Saba A (Istituto Nazionale di Ricerca per gli Alimenti e la Nutrizione - Italy); La Vecchia C; Lombardy B ('Mario Negri' Institute - Italy); Joffe R; Santare D (Center of Food and Veterinary Service of Latvia - Latvia); Barzda A (National Nutrition Center of the Lithuanian Ministry of Health - Lithuania); Pace Asciak R; Calleja N; Ellul V; Grima A (Department of Health Information and Research - Malta); van Rossum C; Ocke M (Rijksinstituut voor Volksgezondheid en Milieu = National Institute or Public Health and the Environment - The Netherlands); Johansson L; Frost-Andersen L, Lande B (University of Oslo - Norway); Szponar L; Charzewska J; Brzozowska A (National Food and Nutrition Institute - Poland); Rywik $\mathrm{S}$ (National Institute of Cardiology - Poland); Barros $\mathrm{H}$; Moreira P; Ramos E; Barros R; Lopes C (University of Porto - Portugal); Zapirtan H; Vlad M (Institute of Public Health - Romania); Gurinovic M; Glibetic M (Department of Nutrition, Institute of Medical Research, University of Belgrade - Serbia); Vukmirovic D; Mijakovac N (Statistical Office Republic Serbia - Serbia); Koch V (University of Ljubljana - Slovenia); Ortega RM (University Complutense of Madrid - Spain); Vioque J (University of Alicante Spain); Tur JA (University of Balearic Islands - Spain); Enghardt Barbier H (NFA and GfK Sweden - Sweden); 
Becker W (National Food Administration and Statistics Sweden - Sweden); Gaspoz JM (University of Geneva Switzerland); Cade J (University of Leeds - United Kingdom) and Margetts B (University of Southampton - United Kingdom). Your collaboration is greatly appreciated!! There is no conflict of interest.

\section{References}

1. Lagiou P, Trichopoulou A \& DAFNE contributors (2001) The DAFNE initiative: the methodology for assessing dietary patterns across Europe using household budget survey data. Public Health Nutr 4, 1135-1141.

2. Trichopoulou A, Naska A \& Oikonomo E (2005) The DAFNE databank: the past and the future of monitoring the dietary habits of Europeans. J Public Health 13, 69-73.

3. EFCOSUM - European Food Consumption Survey Method (1999) Available at: http://ec.europa.eu/health/ph_projects/ 1999/monitoring/monitoring_project_1999_full_en.htm (accessed November 2008).

4. European Food Consumption Validation (EFCOVAL) (2006ongoing) Available at: http://www.efcoval.eu/ (accessed September 2008).

5. The European Prospective Investigation into Cancer and Nutrition (EPIC) (1992-ongoing) Available at: http://epic.iarc. fr/index.php (accessed September 2008).

6. Beer-Borst S, Hercberg S, Morabia A, et al. (2000) Dietary patterns in six European populations: results from EURALIM, a collaborative European data harmonization and information campaign. Eur J Clin Nutr 54, 253-262.

7. Elmadfa I \& Weichselbaum E (editors) (2005) European Nutrition and Health Report 2004. Forum Nutrition, vol. 58 Karger Basel, pp I-XVI.

8. European Nutrition and Health Report 2009. Funded by the European Commission (Public Health Programme 2006) and coordinated by Prof. I. Elmadfa, University of Vienna. Available at: www.univie.ac.at/enhr (accessed November 2008).

9. Morabia A, Beer-Borst S \& Hercberg S (1998) Locally based surveys, unite! The EURALIM example. European Information Campaign on Diet and Nutrition. Am J Public Health 88, 1153-1155.

10. EFSA (2008) Concise European Food Consumption Database. Original idea from the Colloquium on 'European Food Consumption Database - Current and medium to long-term strategies' organised by EFSA in Brussels in April 2005 Available at: http://www.efsa.europa.eu/EFSA/Scientific Panels/DATEX/efsa_locale-1178620753812_ConciseEuropean ConsumptionDatabase.htm (accessed November 2008).

11. Doets EL, de Wit LS, Dhonukshe-Rutten RA, et al. (2008) Current micronutrient recommendations in Europe: towards understanding their differences and similarities. Eur J Nutr 47, Suppl. 1, S17-S40.

12. Ashwell M, Lambert JP, Alles MS, et al. (2008) EURRECA Network. How we will produce the evidence-based EURRECA toolkit to support nutrition and food policy. Eur J Nutr 47 , Suppl. 1, 2-16.

13. Blanquer M, García-Álvarez A, Ribas-Barba L, et al. (2009) Nutrient intake adequacy in European food consumption studies: proposal of a searching strategy. Br J Nutr 101, Suppl. 2, S37-S50.

14. Naska A, Orfanos P, Chloptios I, et al. (2005) Dietary habits in Greece: The European Prospective Investigation into Cancer and nutrition (the EPIC project). Arch Hell Med 22, 259-269 (in Greek).

15. Morabia A (1993) Le Bus Santé, instrument de l'observatoire épidémiologique genevois. (Bus health 2000, instrument of the observatory epidemiological genevois). Cahiers Médico-Sociaux.
16. BUS Santé Surveys (unite mobile du service d'epidemiologie clinique - Observatoire Epidemiologique). (BUS Health Surveys (Service Mobile Unit of Clinical Epidemiology Epidemiologique Observatory)), www.bus-sante.ch/ (accessed November 2008).

17. Babinska K, Bederova A \& Bartekova S (1998) Dietary pattern in the adult population from selected areas of Slovac Republic. Eur J Epidemiol 52, S59.

18. Bederova A, Babinska K \& Bartekova S (1998) Energy and nutrient intake in children and adolescents from eight socioeconomically different regions of Slovakia. Eur J Epidemiol 52, S59.

19. Arvaniti F, Panagiotakos DB, Pitsavos C, et al. (2006) Dietary habits in a Greek sample of men and women: The ATTICA Study. Cent Eur J Publ Health 14, 74-78.

20. Zapirtan H (2006) Dietary imbalance in some colectivities from Transylvania, Romania. Rev Med Chir Soc Med Nat Iasi 110, 993-998.

21. Lopes C, Oliveira A, Santos AC, et al. (2006) Consumo alimentarno Porto (EpiPorto). (Food Consumption in Porto (EpiPorto)) Porto: Faculdade de Medicina do Porto. Available at www.consumoalimentarporto.med.up.pt (accessed November 2008).

22. Serra Majem L, Ribas Barba L, Salvador Castell G, et al. (2006) Avaluació de l'estat nutricional de la població catalana 20022003. Evolució dels hàbits alimentaris i dels consum d'aliments $i$ nutrients a Catalunya (1992-2003) (Assessment of the Nutritional Status of the Population ESTAT Catalana 2002-2003. Evolution of Eating Habits and Nutrients Consumption of Food and Nutrients in Catalonia (1992-2003) Barcelona: Departament de Salut, Generalitat de Catalunya. Available at http://www.gencat.net/salut/depsalut/pdf/encat2003semi.pdf (accessed June 2008).

23. Serra Majem L, (ed). Encuesta Nutricional de Canarias (1997-98). Santa Cruz de Tenerife. Servicio Canario de Salud. vol. 1 (1999): Hábitos alimentarios y consumo de alimentos. vol. 2 (1999). Factores de riesgo cardiovascular. vol. 3 (2000). Ingesta de energía, nutrientes y riesgo de ingestas inadecuadas. vol. 4 (2000). Evaluación bioquímica del estado nutricional. vol. 5 (2000). Conocimientos, opiniones y actitudes. Política de nutrición en Canarias. (Nutrition Survey of the Canary Islands (1997-98). Santa Cruz de Tenerife. Canary Health. vol. 1 (1999): Dietary Habits and Food Consumption. vol. 2 (1999). Cardiovascular Risk Factors. vol. 3 (2000). Intake of Energy, Nutrients and Risk of Inadequate Intakes. vol. 4 (2000). Biochemical Assessment of Nutritional Status. vol. 5 (2000). Knowledge, Opinions and Attitudes. Nutrition Policy in the Canaries), Available at http://www. gobiernodecanarias.org/sanidad/scs/1/plansalud/enca/ ppal_enca. htm (accessed September 2008).

24. Serra Majem L (2000) Evaluación del estado nutricional de la población canaria (1997-98). (Assessment of nutritional status of the population Canaria (1997-98)). Arch Latinoamer Nutr 50, Suppl. 1, 1-70.

25. Tur JA (2002) Nutritional Survey of the Balearic Islands (ENIB, 1999-2000). Revista Ciència 27-30, 1-620.

26. Vioque J \& Quiles J (2003) Encuesta de Nutrición y Salud de la Comunidad Valenciana (1994). (Survey of Nutrition and Health, Valencia (1994)). Alicante: Departamento Salud Pública. Available at http://www.dsp.umh.es/docencia/medprev/encuesta_cv. pdf (accessed November 2008).

27. Institute of Medicine (2000) Dietary Reference Intakes: Applications in Dietary Assessment. Washington, DC: National Academy Press.

28. Roman-Viñas B, Serra-Majem L \& Ribas-Barba L, et al. (2009) Overview of methods used to evaluate the adequacy of nutrient intakes for individuals and populations. Br J Nutr 101, Suppl. 2, S6-S11. 
29. De Vriese S, Huybrechts I \& Moreau M, et al. Enquête de consommation alimentaire Belge 1-2004: Rapport. Institut Scientifique de Santé Publique, Rapport: D/2006/2505/16. (Survey of Food Consumption Belge 1-2004: Report. Scientific Institute of Public Health Report: D/2006/2505/16). http://www.iph. fgov.be/epidemio/epien/index5.htm (accessed November 2008).

30. Baykova D, Duleva V, Petrova S, et al. (2004) National monitoring of dietary intake and nutritional status of Bulgarian population. Department of Nutrition and Public Health, National Center of Public Health Protection, Sofia, Bulgaria.

31. Ruprich J, Dofkova M \& Rehurkova I, et al. (2006) Individual food consumption - the national study SISP04. Prague: $\mathrm{CHFCH}$ NIPH, available at http://www.chpr.szu.cz/spotrebapotravin.htm (accessed November 2008).

32. Lyhne N, Christensen T \& Groth MV (2005) Danskernes kostvaner 2000-2002. Hovedresultater. (ShopperTrends Diets 20002002. Main Results) (Dietary Habits in Denmark 2000-02). Søborg: National Food Institute, available at http://www.dfvf. $\mathrm{dk} /$ Default.aspx? $\mathrm{ID}=20450$ (accessed November 2008).

33. Pomerleau J, McKee M, Robertson A, et al. (2000) Nutrition and lifestyle in the Baltic RepublicsPHP Departmental Publication No. 32. London: London School of Hygiene and Tropical Medicine.

34. Pomerleau J, Mckee M, Robertson A, et al. (2001) Macronutrient and food intake in the Baltic Republics. Eur J Clin Nutr 55, 200-207.

35. Männistö S, Ovaskainen M.-L, Valsta L, et al. (2003) Finravinto 2002tutkimus B3/2003. The National FINDIET 2002 Study. Kansanterveyslaitoksen julkaisuja. (Finravinto 2002-R. The National FINDIET 2002 Study. Public Health Institute's Publications B3/2003). Helsinki: Kansanterveyslaitos, Ravitsemusyksikkö.

36. Castetbon K \& Hercberg S (2007) Unité de surveillance et d'épidémiologie nutritionnelle (Usen). Etude nationale nutrition santé (ENNS, 2006). Situation nutritionnelle en France en 2006 selon les indicateurs d'objectif et les repères du Programme national nutrition santé (PNNS). Institut de veille sanitaire. (Monitoring Unit of Epidemiology and Nutrition (Usen). National Nutrition Health Survey (ENNS, 2006). Nutritional Situation in France in 2006. According to Objective Indicators and Benchmarks of the National Nutrition Santé (PNNS)): Université de Paris 13, Conservatoire national des arts et métiers $74 \mathrm{p}$.

37. Brombach C, Wagner U, Eisinger-Watzl M, et al. (2006) The National Nutrition Survey II, Ernaehrungs-Umschau 53, 4-9.

38. Biró L, Zajkás G, Greiner E, et al. (2007) Hungarian national dietary survey, 2003-2004. Micronutrients: mineral salts. Orv Hetil 148, 703-708.

39. Steingrímsdóttir L, Porgeirsdóttir H \& Ólafsdóttir AS (2003) The Diet of Icelanders, Dietary Survey of The Icelandic Nutrition Council 2002, Main Findings. Reykjavík: Public Health Institute (previously Icelandic Nutrition Council). Available at http://lydheilsustod.is/media/manneldi/rannsoknir/skyrsla.pdf (accessed November 2008) (in Icelandic).

40. Kiely M (2001) North/South Ireland Food Consumption Survey - by IUNA (Irish Universities Nutrition Alliance). Dublin: Food Safety Promotion Board.

41. Turrini A \& Leclercq C (2006) Food Consumption Survey INRAN-SCAI 2005-2006. Rome: Istituto Nazionale di Ricerca per gli Alimenti e la NUtrizione (INRAN).

42. Pace Asciak R, Dalmas M, Gatt M, et al. (2003) The First National Health Interview Survey (HIS Malta 2002). Malta: Department of Health Information and Research, Available at http://www.sahha.gov.mt/pages.aspx?page $=384$ (accesssed November 2008).

43. Anonymous (1998) Zo eet Nederland, 1998. Results of the Dutch National Food Consumption Survey 1997-1998.
The Hague: Netherlands Nutrition Centre, Reference publication: Hulshof KFAM \& van Staveren WA. (1991) Food policy 16, 257-260.

44. Johansson L \& Solvoll K (1998) NORKOST 1997: Landsomfattende kostholdsunders $\emptyset$ kelse blant menn og kvinner i alderen 16-79 år. Rapport nr. 2. (NORKOST 1997: Nationwide Kostholdsundersøkelse among Men and Women Aged 16-79 Years. Report No. 2), http://www.shdir.no/vp/multimedia/ archive/00003/IS-0168_3745a.pdf (accessed November 2008) (in Norwegian).

45. Szponar L, Sekula W, Rychlik E, et al. (2003) Badania indywidualnego spozycia zywnosci $i$ stanu odzywienia $w$ gospodarstwach domowych (The Study of Individual Food Consumption and Nutritional Status in the Household) (Household Food Consumption and Anthropometric Survey). Warsaw: Publication of the National Food and Nutrition Institute.

46. Graça MJ, Dias CM, Rodrigues F, et al. (2001) Inquérito nacional de saúde - Dados Gerais - Continente 98/99. (National Health Survey - General Data - Mainland 98/99): Observatório Nacional de Saúde.

47. Pavlović M, Majkic SN, Bolits Z, et al. (2001) Nutrition as the potential risk factor of atherosclerosis. Jugoslov Med Biohem 20, $107-115$.

48. Pavlović M \& Grujić V (2003) Nutritive risk factors within the population. Book of Proceedings: 1st International Symposium 'Food in the 21st Century', pp. 474-481.

49. Koch V \& Pokorn D (1999) Some differences in nutritional habits between males and females in the Republic of Slovenia. Food Technol Biotechnol 37, 181-186.

50. Koch V \& Pokorn D (1999) Comparison of nutritional habits among various adult age groups in Slovenia, (N.Y. N.Y.). (Print ed.). Nutr Res 19, 1153-1164.

51. Estudio EnKid (EnKid study). [L Serra Majem and J Aranceta Bartrina (editors). vol. 1 (2000): Desayuno y equilibrio alimentario. vol. 2 (2001). Obesidad infantil y juvenil. vol. 3 (2002). Alimentación infantil y juvenil. vol.4(2003). Crecimiento y desarrollo. Krece Plus. vol. 5 (2004). Nutrición infantil y juvenil. vol. 6 (2006). Actividad física y salud (vol. 1 (2000): Breakfast and Balanced Diet. vol. 2 (2001). Obese Children and Adolescents. vol. 3 (2002). Infant and Juvenile. vol. 4 (2003). Growth and Development. Krece Plus. vol. 5 (2004). And Young Child Nutrition. vol. 6 (2006). Physical Activity and Health): Masson Barcelona.

52. Becker W \& Pearson M Riksmaten 1997-98 (National Food 1997-98), Available at http://www.slv.se/templates/SLV_Page. aspx id $=12429$ \&epslanguage $=$ SV Uppsala: Livsmedelsverket (accessed November 2008).

53. Henderson L, Gregory J \& Swan G (2002) National Diet and Nutrition Survey: Adults Aged 19 to 64 Years. vol. 1: Types and Quantities of Foods Consumed. London: The Stationery Office.

54. Henderson L, Gregory J, Irving K, et al. (2003) The National Diet and Nutrition Survey: Adults Aged 19 to 64 Years. vol. 2: Energy, Protein, Carbohydrate, Fat and Alcohol Intake. London: The Stationery Office.

55. Henderson L, Irving K, Gregory J, et al. (2003) The National Diet and Nutrition Survey: Adults Aged 19 to 64 Years. vol. 3: Vitamin and Mineral Intake and Urinary Analytes. London: The Stationery Office.

56. Ruston D, Hoare J, Henderson L, et al. (2004) The National Diet and Nutrition Survey: Adults Aged 19 to 64 Years: vol. 4: Nutritional Status (Anthropometry and Blood Analytes), Blood Pressure and Physical Activity. London: The Stationery Office.

57. Hoare J, Henderson L, Bates CJ, et al. (2004) National Diet and Nutrition Survey: Adults Aged 19 to 64 Years. vol. 5: Summary Report. London: The Stationery Office. 